\title{
PSA Level Twenty to One Hundred Fifty
}

National Cancer Institute

\section{Source}

National Cancer Institute. PSA Level Twenty to One Hundred Fifty. NCI Thesaurus. Code C159777.

A blood concentration of prostate specific antigen between $20 \mathrm{ng} / \mathrm{mL}$ and $150 \mathrm{ng} / \mathrm{mL}$. 